\title{
Emerging Non Fermentative Gram Negative Bacteria and their Antibiogram from Various Clinical Samples Collected from Patient Admitted to Medical Intensive Care Units
}

\author{
Anirudh*, Anil Bilolikar and Sukrutha Gopal Reddy \\ Department of Microbiology, Krishna Institute of Medical Sciences, Minister Road, \\ Secunderabad - 500003, T.S., India \\ *Corresponding author
}

\section{A B S T R A C T}

Keywords

NFGNB, MICU, MIC, Pseudomonas aeruginosa, Elizabethkingia meningoseptica

Article Info

Accepted: 20 June 2021 Available Online: 20 July 2021
Non fermentors are important noscomial pathogens causing opportunistic infections in immunocompromised patients. They cause infections with patients having humidifiers, ventilators and catheter devices especially in medical intensive care units. To isolate identify in which age group, sex, risk factors of non fermentative gram negative bacteria The study was performed from September 2018 to February 2019 for a period of 6 months in Department of Microbiology\& Medical Intensive Care Units. The samples were inoculated on Blood agar, Mac Conkey agar and incubated at $37^{\circ} \mathrm{C}$ for overnight. Non-lactose fermentation was noted on MacConkey agar. The isolates were identified and Antimicrobial susceptibility testing was done by using GN card and AST N281 respectively by using Vitek 2 compact (Biomerieux). A total of 3143 clinical samples were obtained from medical intensive care units. 100 NFGNB were isolated with prevalence of 3.18. Males are more predominant than females. The most common age group in which non fermenters were isolated is 61-70 years followed by 51-60 years. Among the Acinetobacter baumanii $(\mathrm{n}=40)$ maximum sensitivity is seen in colistin followed by tigecycline. And among Pseudomonas aeruginosa $(n=38)$ maximum sensitivity is for colistin and gentamycin.

\section{Introduction}

Non fermenting gram negative bacteria (NFGNB) are non sporing, aerobic bacteria which do not ferment glucose and and have positive cytochrome oxidase test and usually they do not grow on MacConkey agar ${ }^{1}$. They account for $10-15 \%$ of all bacterial isolates and cause life threatening infections such as septicemia, surgical site infection, wound infection, meningitis, osteomyelitis and pneumonia ${ }^{2}$.

Majority of non fermentating gram negative bacteria emerged as important nosocomial pathogens causing opportunistic infections in immune compromised patients ${ }^{3}$. The source of establishing infections for these non 
fermentating gram negative bacteria are dialysis units, humidifiers, ventilator machines, catheter devices ${ }^{4}$.The predominant non fermentors are Pseudomonas aeruginosa, Acinetobacter baumanni followed by Burkholderia cepacia, Stenotrophomonas maltophila, Elizabethkingae, Chryseobacterium and Alcaligenes species. Routinely they are identified only in a few laboratories in India as they grow slowly and require special culture media and other biochemical tests for identification ${ }^{5}$. Pseudomonas aeruginosa infection is prevalent among patients with, acute leukemia, organ transplants and intravenous injections. Infections usually tends to accumulate where moisture occurs in sites such as tracheostomy site, indwelling catheters, burns, the external ear and weeping cutaneous wounds. Intensive care units(ICU) are more prone to vulnerable population and the emergence of non fermenting gram negative bacteria and their resistance to several antibiotics has raised a severe issue in predicting patient treatment outcomes.

The aim of the study is to identify in which age group, sex and risk factors are present to, isolate, identify and characterize, prevalence of non fermenting Gram negative bacteria and their antibiotic sensitivity from various clinical samples in Medical Intensive Care Units. Among the NFGNB isolated most common was Acinetobacter baumanii (40) followed by Pseudomonas aeruginosa (38), Elizabethkingia meningoseptica Burkholderia cepacia (4), Stenotrophomonas maltophila (4), Ralstonia picketti (2), Pseudomonas spp (2), Sphingomonas spp (3).

\section{Materials and Methods}

It was a prospective, analytical, observational study performed in the Krishna Institute of Medical Sciences. The study was performed from September 2018 to February 2019 for a period of 6 months in Department of Microbiology \& Medical Intensive Care Units. The samples were inoculated on Blood agar, Mac Conkey agar and incubated at $37^{\circ}$ for overnight. Non-lactose fermentation was noted on MacConkey agar. Preliminary identification of non fermenting gram negative bacteria was done by Gram staining, motility, oxidase and catalase test.

The isolates were identified and Antimicrobial susceptibility testing was done by using GN card and AST N281 respectively by using Vitek 2 compact (Biomerieux). The quality control of GN card (identification testing) was done by using ATCC 700323 Enterobacter hormaechei, ATCC 17666 Stenotrophomonas maltophilia, ATCC 700327 Enterococcus casseliflavus, ATCC BAA 750 Staphylococcus saprophyticus. The quality control of AST N281 card (Antimicrobial susceptibility testing) was done by using ATCC 25922 Enterococcus fecalis, ATCC 27853 Pseudomonas aeruginosa, ATCC 35218 Escherichia coli. Antimicrobial susceptibility testing in which MIC values were reported as per CLSI 2018 \& 2019 guidelines $^{29}$.

\section{Results and Discussion}

A total of 3143 clinical samples were obtained from medical intensive care units. 100 NFGNB were isolated with prevalence of 3.18. Males $\mathrm{n}=77(77 \%)$ and females were $n$ $=23(23 \%)$. Males are more predominant than females.

The most common age group in which non fermenters were isolated is 61-70 years followed by 51-60 years,71-80 years and 8190 years.

Among the NFGNB isolated most common was Acinetobacter baumanii (40) followed by Pseudomonas aeruginosa

(38), 
Elizabethkingia meningoseptica (7), Burkholderia cepacia (4), Stenotrophomonas maltophila (4), Ralstonia picketti (2), Pseudomonas spp (2), Sphingomonas spp (3).

Among the Acinetobacter baumanii $(\mathrm{n}=40)$ maximum sensitivity is seen in colistin followed by tigecycline and maximum resistance is piperacillin tazobactum, amikacin and aztreonam. And among Pseudomonas aeruginosa $(n=38)$ maximum sensitivity is for colistin and gentamycin.

Among the risk factors, most common risk factor for isolation of NFGNB is catheter associated and more number of isolates are presented with more than 5 risk factors.

Non fermenters are intrinsically resistant to various antimicrobials and are known to produce Extended spectrum beta lactamases (ESBL's) and metallobeta lactamases (MBL's).

In the present study maximum NFGNB were isolated in the age group of 61-70years(29\%) which is comparable to study done by Mushtaq ${ }^{6}$ et al., where maximum number of NFGNB are obtained in the age group above 60 years 21(39.6\%). This could be due to comorbidities present in the geriatric age group, making them prone to diseases due to lesser immunity. This differs from studies conducted by Maniyan ${ }^{7}$ et al., showing maximum number of non fermentors isolated in age group of less than 10 years $23(20.91 \%$ ) followed by $21-30$ years $21(19.09 \%)$ and least in age 60 years $21(19.09 \%)$.

In this study, NFGNB are observed more in males $(77 \%)$ than in females $(23 \%)$, which correlates to studies done by Ridhima ${ }^{8}$ et al., where NFGNB isolated in males and females were $69.7 \%$ and $30.3 \%$ respectively. In a study conducted by Kalidas ${ }^{9}$ et al., NFGNB were isolated in 55\% males and $45 \%$ females. In the present study, the prevalance of NFGNB was $3.18 \%$, which is comparable to Benachinmardi ${ }^{10}$ et al., (3.5\%) and Bruno ${ }^{11}$ et al., (2.18\%). In studies conducted by Bhuvaneshwari $\mathrm{G}^{12}$, Khante ${ }^{13}$ et al., the prevalence was $6.85 \%$ and $8.67 \%$ respectively. This is due to demographic and epidemiological variation of other studies mentioned as they have included all the intensive care units because of which their rate of NFGNB isolation is high. The low isolation rate in our study may be due to strict infection control practices and implementation of antibiotic stewardship programme.

In the present study maximum number of isolates are obtained from Endotracheal secretion $(50 \%)$ followed by Sputum (19\%), bronchial wash $(8 \%)$ and blood $(8 \%)$. The study is comparable to study done by Mushtaq ${ }^{6}$ et al., and Harris et al., where respiratory samples accounted for $39.6 \%$ and $50 \%$ respectively.

The organisms isolated are Acinetobacter baumanii (40\%), followed by Pseudomonas aeruginosa (38\%), Elizabethkingae meningoseptica (7\%), Burkholderia cepacia (4\%), Stenotrophomonas malthophilia (4\%), Ralstonia picketti (2\%), Sphingomonas paucimobilis (2\%), Pseudomonas putida $(1 \%)$, Pseudomonas luteola (1\%), Sphingomonas spiritivorum $(1 \%)$.

In the present study Acinetobacter baumanii $(40 \%)$ is the most common isolate followed by Pseudomonas aeruginosa $(38 \%)$. This is comparable from study done by Samanta ${ }^{14}$ et al., where Acinetobacter baumanii and Pseudomonas aeruginosa accounted for $66 \%$ and $26 \%$ of the isolates respectively. 
Table.1 The various antibiotics and their minimal inhibitory concentration (MIC) interpretive criteria with susceptible, intermediate and resistant MICs for NFGNB as given by CLSI (20182019) as mentioned in the table.

\begin{tabular}{|c|c|c|c|c|}
\hline \multirow{2}{*}{ S.No. } & Name of the Antibiotic & \multicolumn{3}{|c|}{ MIC Interpretive Criteria $(\boldsymbol{\mu g} / \mathbf{M I})$} \\
\cline { 3 - 5 } & & $\mathbf{S}$ & $\mathbf{I}$ & $\mathbf{R}$ \\
\hline $\mathbf{0 1}$ & Ticarcillin+Clavulanic acid & $\leq 16$ & $32-64$ & $\geq 128$ \\
\hline $\mathbf{0 2}$ & Piperacillin+Tazobactum & $\leq 16$ & $32-64$ & $>128$ \\
\hline $\mathbf{0 3}$ & Ceftazidime & $\leq 8$ & 16 & $\geq 32$ \\
\hline $\mathbf{0 4}$ & Cefaperazone+Sulbactum & $\leq 8$ & - & $\geq 32$ \\
\hline $\mathbf{0 5}$ & Cefepime & $\leq 8$ & 16 & $\geq 32$ \\
\hline $\mathbf{0 6}$ & Aztreonam & $\leq 8$ & 16 & $\geq 32$ \\
\hline $\mathbf{0 7}$ & Doripenem & $\leq 2$ & 4 & $\geq 8$ \\
\hline $\mathbf{0 8}$ & Imipenem & $\leq 2$ & 4 & $\geq 8$ \\
\hline $\mathbf{0 9}$ & Meropenem & $\leq 2$ & 4 & $\geq 8$ \\
\hline $\mathbf{1 0}$ & Amikacin & $\leq 16$ & 32 & $\geq 64$ \\
\hline $\mathbf{1 1}$ & Gentamycin & $\leq 4$ & 8 & $\geq 16$ \\
\hline $\mathbf{1 2}$ & Ciprofloxacin & $\leq 0.5$ & 1 & $\geq 2$ \\
\hline $\mathbf{1 3}$ & Levofloxacin & $\leq 1$ & 2 & $\geq 4$ \\
\hline $\mathbf{1 4}$ & Minocycline & $\leq 4$ & 8 & $\geq 16$ \\
\hline $\mathbf{1 5}$ & Tigecycline & $\leq 2$ & 4 & $\geq 8$ \\
\hline $\mathbf{1 6}$ & Colistin & $\leq 2$ & - & $\geq 4$ \\
\hline $\mathbf{1 7}$ & Cotrimoxazole & $\leq 40$ & - & $\geq 80$ \\
\hline
\end{tabular}

Fig.1 Age wise distribution of patients

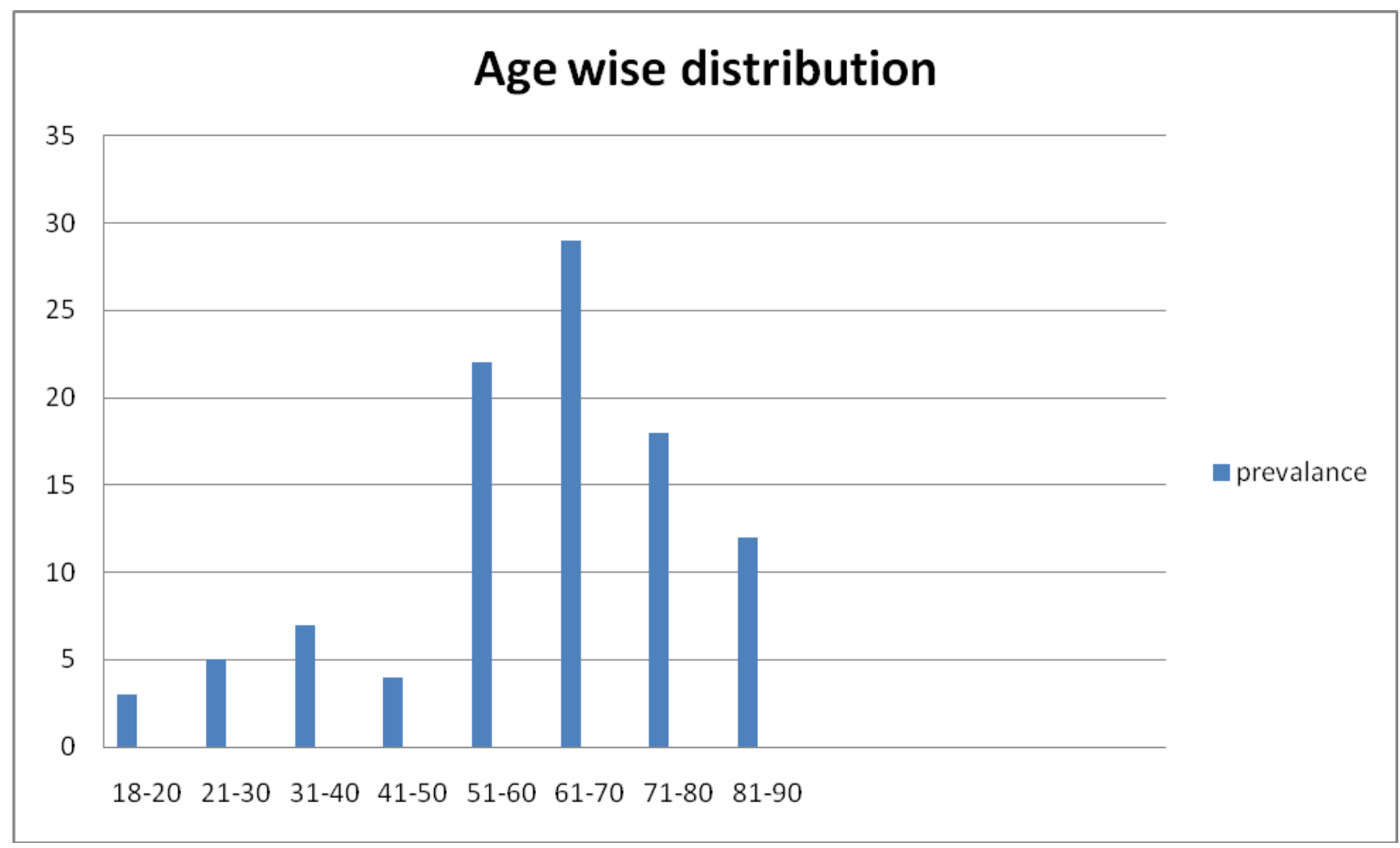


Table.2 Age wise distribution of patients in whom NFGNB were isolated.

\begin{tabular}{|c|c|c|c|c|c|c|c|c|}
\hline Age group & $\mathbf{1 8 - 2 0}$ & $\mathbf{2 1 - 3 0}$ & $\mathbf{3 1 - 4 0}$ & $\mathbf{4 1 - 5 0}$ & $\mathbf{5 1 - 6 0}$ & $\mathbf{6 1 - 7 0}$ & $\mathbf{7 1 - 8 0}$ & $\mathbf{8 1 - 9 0}$ \\
\hline prevalance & $3(3 \%)$ & $5(5 \%)$ & $7(7 \%)$ & $4(4 \%)$ & $22(22 \%)$ & $29(29 \%)$ & $18(18 \%)$ & $12(12 \%)$ \\
\hline
\end{tabular}

Table.3 Prevalance of NFGNB from various clinical samples .

\begin{tabular}{|c|c|c|c|c|c|c|c|c|c|c|}
\hline Organism & $\begin{array}{c}\text { Et } \\
\text { secretion }\end{array}$ & Blood & $\begin{array}{l}\text { Urine } \\
\text { clean }\end{array}$ & $\begin{array}{l}\text { Urine } \\
\text { catheter } \\
\text { catch }\end{array}$ & Pus & $\begin{array}{l}\text { Bronchial } \\
\text { wash }\end{array}$ & Sputum & $\begin{array}{l}\text { Body } \\
\text { fluids }\end{array}$ & $\begin{array}{c}\text { Catheter } \\
\text { tip }\end{array}$ & Total \\
\hline $\begin{array}{c}\text { Pseudomonas } \\
\text { aeruginosa }\end{array}$ & 15 & 2 & 2 & 1 & 3 & 1 & 12 & 1 & 1 & 38 \\
\hline $\begin{array}{c}\text { Acinetobacter } \\
\text { baumanii }\end{array}$ & 21 & 2 & 0 & 0 & 2 & 6 & 6 & 2 & 1 & 40 \\
\hline $\begin{array}{l}\text { Burkholderia } \\
\text { cepacia }\end{array}$ & 2 & 2 & & & & & & & & 4 \\
\hline $\begin{array}{l}\text { Elizabethkingae } \\
\text { meningoseptica }\end{array}$ & 6 & 1 & & & & & & & & 7 \\
\hline Ralstonia picketti & 1 & 1 & & & & & & & & 2 \\
\hline $\begin{array}{c}\text { Stenotrophomonas } \\
\text { maltophila }\end{array}$ & 3 & & & & & 1 & & & & 4 \\
\hline $\begin{array}{l}\text { Sphingomonas } \\
\text { paucimobilis }\end{array}$ & & & & & & & 1 & & 1 & 2 \\
\hline $\begin{array}{c}\text { Pseudomonas } \\
\text { luteola }\end{array}$ & 1 & & & & & & & & & 1 \\
\hline $\begin{array}{c}\text { Pseudomonas } \\
\text { putida }\end{array}$ & & & & 1 & & & & & & 1 \\
\hline $\begin{array}{l}\text { Sphingomonas } \\
\text { spiritivorum }\end{array}$ & 1 & & & & & & & & & 1 \\
\hline Total & 50 & 8 & 2 & 2 & 5 & 8 & 19 & 3 & 3 & 100 \\
\hline
\end{tabular}


Table.4 Antibiotic susceptibility pattern of Acinetobacter baumanii and Pseudomonas aeruginosa to various antibiotics tested

\begin{tabular}{|c|c|c|c|c|c|c|}
\hline \multirow[t]{2}{*}{ Antibiotic } & \multicolumn{3}{|c|}{ Pseudomonas aeruginosa $(\mathrm{n}=38)$} & \multicolumn{3}{|c|}{ Acinetobacter baumanii $(\mathrm{n}=40)$} \\
\hline & $\begin{array}{c}\text { sensitiv } \\
\mathrm{e}\end{array}$ & $\begin{array}{l}\text { intermedia } \\
\text { te }\end{array}$ & resistant & sensitive & intermediate & resistant \\
\hline $\begin{array}{l}\text { Ticarcillin+ } \\
\text { clavunilic acid }\end{array}$ & $\begin{array}{c}14(36.8 \\
\%)\end{array}$ & $7(18.4 \%)$ & $17(44.7 \%)$ & $2(5 \%)$ & & $38(95 \%)$ \\
\hline $\begin{array}{l}\text { Piperacillin } \\
\text { Tazobactum }\end{array}$ & $\begin{array}{c}21(55.2 \\
\%)\end{array}$ & $2(5.2 \%)$ & $15(39.4 \%)$ & $1(2.5 \%)$ & & $39(97.5 \%)$ \\
\hline Ceftazidime & $\begin{array}{c}26(68.4 \\
\%)\end{array}$ & $2(5.2 \%)$ & $10(26.3 \%)$ & $2(5 \%)$ & & $38(95 \%)$ \\
\hline $\begin{array}{c}\text { Cefaperazone } \\
\text { sulbactum }\end{array}$ & $\begin{array}{c}24(63.1 \\
\%)\end{array}$ & $3(7.8 \%)$ & $11(28.9 \%)$ & $3(7.5 \%)$ & $5(12.5 \%)$ & $32(80 \%)$ \\
\hline Cefepime & $\begin{array}{c}26(68.4 \\
\%)\end{array}$ & $2(5.2 \%)$ & $10(26.3 \%)$ & $2(5 \%)$ & & $38(95 \%)$ \\
\hline Aztreonam & $\begin{array}{c}17(44.7 \\
\%)\end{array}$ & $5(13.1 \%)$ & $16(42.1 \%)$ & $1(2.5 \%)$ & & $39(97.5 \%)$ \\
\hline Doripenem & $\begin{array}{c}25(65.7 \\
\%)\end{array}$ & $3(7.8 \%)$ & $10(26.3 \%)$ & $2(5 \%)$ & & $38(95 \%)$ \\
\hline Imipenem & $\begin{array}{c}26(68.4 \\
\%)\end{array}$ & & $12(31.5 \%)$ & $2(5 \%)$ & & $38(95 \%)$ \\
\hline Meropenem & $\begin{array}{c}24(63.1 \\
\%)\end{array}$ & $1(2.6 \%)$ & $13(34.2 \%)$ & $1(2.5 \%)$ & $1(2.5 \%)$ & $38(95 \%)$ \\
\hline Amikacin & $\begin{array}{c}27(71.1 \\
\%)\end{array}$ & $1(2.6 \%)$ & $10(26.3 \%)$ & $1(2.5 \%)$ & & $39(97.5 \%)$ \\
\hline Gentamycin & $\begin{array}{c}28(73.6 \\
\%)\end{array}$ & $1(2.6 \%)$ & $9(23.6 \%)$ & $3(7.5 \%)$ & $2(5 \%)$ & $35(87.5 \%)$ \\
\hline Ciprofloxacin & $\begin{array}{c}23(60.5 \\
\%)\end{array}$ & $1(2.6 \%)$ & $14(36.8 \%)$ & $2(5 \%)$ & & $38(95 \%)$ \\
\hline levofloxacin & $\begin{array}{c}21(55.2 \\
\%)\end{array}$ & & $17(44.7 \%)$ & $2(5 \%)$ & $1(2.5 \%)$ & $37(92.5 \%)$ \\
\hline Minocycline & & & & $18(45 \%)$ & $4(10 \%)$ & $18(45 \%)$ \\
\hline Tigecycline & & & & $37(92.5 \%)$ & $2(5 \%)$ & $1(2.5 \%)$ \\
\hline Colistin & $\begin{array}{c}38(100 \\
\%)\end{array}$ & & & $40(100 \%)$ & & \\
\hline Cotrimoxazole & & & & & & \\
\hline
\end{tabular}


Table.5 Antibiotic susceptibility pattern of Burkholderia cepacia and Stenotrophomonas maltophilia to various antibiotics tested.

\begin{tabular}{|c|c|c|c|c|c|c|}
\hline \multirow[t]{2}{*}{ Antibiotic } & \multicolumn{3}{|c|}{ Burkholderia cepacia $(\mathrm{n}=4)$} & \multicolumn{3}{|c|}{ Stenotrophomonas maltophilia $(\mathrm{n}=4)$} \\
\hline & $\mathrm{S}$ & I & $\mathrm{R}$ & $\mathrm{S}$ & I & $\mathrm{R}$ \\
\hline $\begin{array}{c}\text { Ticarcillin+ } \\
\text { Clavunalic acid }\end{array}$ & & & $4(100 \%)$ & $4(100 \%)$ & & \\
\hline Ceftazidime & $4(100 \%)$ & & & $3(75 \%)$ & & $1(25 \%)$ \\
\hline Meropenem & $2(50 \%)$ & $1(25 \%)$ & $1(25 \%)$ & NA & NA & NA \\
\hline levofloxacin & $1(25 \%)$ & $2(50 \%)$ & $1(25 \%)$ & $4(100 \%)$ & & \\
\hline Minocycline & $2(50 \%)$ & $1(25 \%)$ & $1(25 \%)$ & $4(100 \%)$ & & \\
\hline Cotrimoxazole & $3(75 \%)$ & & $1(25 \%)$ & $4(100 \%)$ & & \\
\hline
\end{tabular}

Table.6 Antibiotic susceptibility pattern of Elizabethkingae meningoseptica to various antibiotics tested

\begin{tabular}{|c|c|c|c|}
\hline Antibiotic & \multicolumn{3}{|c|}{ Elizabethkingae meningoseptica $(\mathbf{n}=7)$} \\
\hline & $\mathrm{S}$ & $\mathrm{I}$ & $\mathrm{R}$ \\
\hline Rifampicin & $6(85.7 \%)$ & & $1(14.2 \%)$ \\
\hline Cotrimoxazole & $6(85.7 \%)$ & & $1(14.2 \%)$ \\
\hline Ciprofloxacin & $4(57.1 \%)$ & $1(14.2 \%)$ & $2(28.5 \%)$ \\
\hline Clindamycin & $5(71.4 \%)$ & & $2(28.5 \%)$ \\
\hline vancomycin & $7(100 \%)$ & & \\
\hline Minocycline & $7(100 \%)$ & & \\
\hline
\end{tabular}

Table.7 Number of Risk factors in study population.

\begin{tabular}{|c|c|c|c|c|c|c|c|}
\hline $\begin{array}{c}\text { Total no of } \\
\text { patients }\end{array}$ & $\begin{array}{c}\mathbf{1} \text { risk } \\
\text { factor }\end{array}$ & $\begin{array}{c}\mathbf{2} \text { risk } \\
\text { factors }\end{array}$ & $\begin{array}{c}\mathbf{3} \text { risk } \\
\text { factors }\end{array}$ & $\begin{array}{c}\text { 4 risk } \\
\text { factors }\end{array}$ & $\begin{array}{c}\mathbf{5} \text { risk } \\
\text { factors }\end{array}$ & $\begin{array}{c}\mathbf{6} \text { risk } \\
\text { factors }\end{array}$ & $\begin{array}{c}\mathbf{7} \text { risk } \\
\text { factors }\end{array}$ \\
\hline 100 & 1 & 9 & 21 & 17 & 24 & 22 & 6 \\
\hline
\end{tabular}

Table.8 Risk factor wise distribution of patients of NFGNB isolated

\begin{tabular}{|c|c|}
\hline Risk factor & Number of patients \\
\hline Hypertension & 47 \\
\hline Diabetes & 52 \\
\hline Catheter associated & 98 \\
\hline Iv canula associated & 75 \\
\hline Central line associated & 64 \\
\hline Ventilator associated & 75 \\
\hline wound associated & 34 \\
\hline
\end{tabular}


Fig.2 Total number of NFGNB isolated

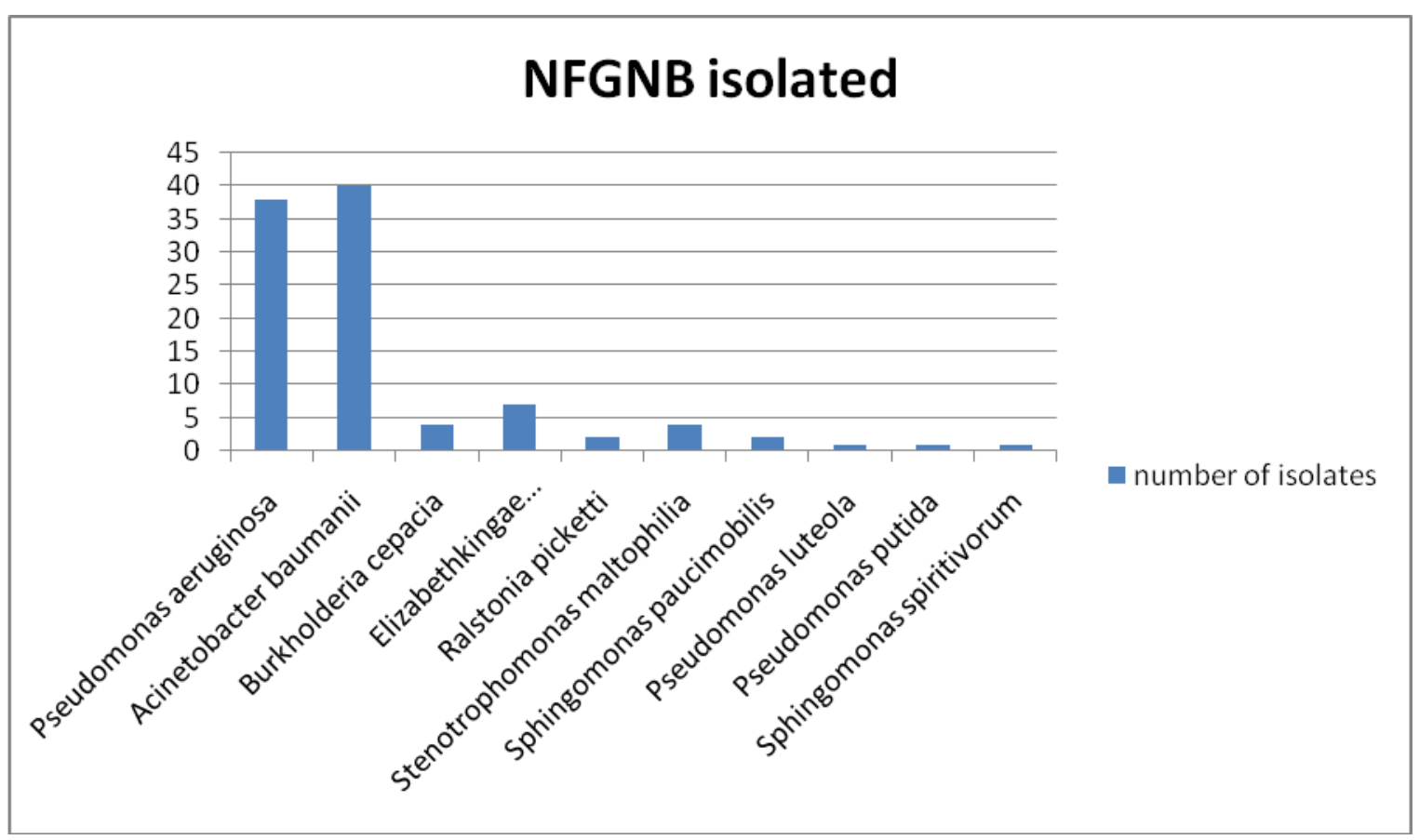

However, this differs from studies done by Eltahawy and khalaf $^{15}$ where Acinetobacter baumanii and Pseudomonas aeruginosa accounted for $34 \%$ and $31 \%$ respectively. Also, in studies conducted by Wang $\mathrm{H}^{16}$ et al., Acinetobacter baumanii was isolated in 56\% of the isolates, followed by Pseudomonas aeruginosa (46.9\%). These studies are more of western in origin and they have considered all the intensive care units whereas our study is only medical intensive care units.

Among Endotracheal secretions, the Acinetobacter baumanii was the most common isolate (42\%), followed by Pseudomonas aeruginosa (30\%). These findings are similar to study done by Benachinmardi $^{10}$ et al., where the most common isolate among ET secretions was Acinetobacter baumanii (41\%). Also, in a study conducted by maniyan ${ }^{7}$ et al., Acinetobacter baumanii accounted for $80 \%$ of ET secretion isolates and Pseudomonas aeruginosa accounted for $20 \%$. On the contrary, this study differs from a study conducted by Sudha Krishnan ${ }^{17}$ et al., where the isolation rate of Acinetobacter baumanii is $36.7 \%$ and Pseudomonas aeruginosa is $53.9 \%$.

Among the sputum samples, most number of isolates are Pseudomonas aeruginosa (63.1\%) followed by Acinetobacter baumanii (31.5\%). These findings correlate with Benachinmardi ${ }^{10}$ et al., Khante ${ }^{13}$ et al., Kaur ${ }^{18}$ et al., where Pseudomonas aeruginosa and Acinetobacter baumanii were $43 \%$ and $78 \%$ respectively. In a study conducted by Malini ${ }^{2}$ et al., Pseudomonas aeruginosa and Acinetobacter baumanii accounted for $23 \%$ and $16.3 \%$ of the sputum isolates, respectively.

In the study, the antibiotic senstivity of Acinetobacter baumanii to colistin is $100 \%$ and to tigecycline is $92.5 \%$. Similarly, in a study by Nazir ${ }^{19}$ et al., sensitivity of Acinetobacter baumanii to colistin is $100 \%$ to tigecycline $(84 \%)$. However, the findings of Baruah $^{20}$ et al., showed variation from present study to colistin suspectibility (12.5\%). 
In the study Acinetobacter baumanii showed maximum resistance to Piperacillin Tazobactum (97.5\%), Amikacin (97.5\%)and Aztreonam (97.5\%). Study done by Memish ${ }^{21}$ et al., showed maximum resistance to Aztreonam (95.5\%) and Amikacin(76.9\%) and study done by Kaur $^{18}$ et al., showed maximum resistance to Amikacin (90\%)and Piperacillin tazobactum $(87 \%)$. Whereas, in a Study done by Jithendranath ${ }^{22}$ et al., Maniyan ${ }^{7}$ et al., there was least resistance to Piperacillin tazobactum (15\% and $27 \%$ respectively). A study done by Prasanna $^{23}$ et al., there was least resistance to piperacillin tazobactum (4.3\%) and Amikacin (2.6\%).

In the study, Pseudomonas aeruginosa showed $100 \%$ sensitive to Colistin (100\%) and Gentamycin (73.6\%) which is similar to studies done by Parajuli ${ }^{24}$ et al., Khante ${ }^{13}$ et al., Prasanna ${ }^{23}$ et al., Kaur ${ }^{18}$ et al., where Pseudomonas aeruginosa is sensitive to colistin (100\%), (100\%), (95.3\%), (100\%) and gentamycin were $(62.5 \%),(52 \%),(94.7 \%)$, $(55 \%)$ respectively.

Pseudomonas aeruginosa is intrinsically resistant to Minocycline, Tigecycline and Cotrimoxazole as per CLSI 2018 guidelines.

In the study, Pseudomonas aeruginosa is maximum resistant to levofloxacin $(44.7 \%)$. It is similar to study done by $\mathrm{Khante}^{13}$ et al., where levofloxacin (44.87\%). In the study, Pseudomonas aeruginosa is maximum resistant to ticarcillin+clavunilic acid (44.7\%) and it is similar to study conducted by Juyal ${ }^{25}$ et al., where ticarcillin+ clavunilic acid is (30\%). In the present study Pseudomonas aeruginosa are resistant to several antibiotics because of low permeability of the outer membrane, constitutive expression of various efflux pumps, and production of antibiotic inactivating enzymes.

Elizabethkingae meningoseptica has also been reported to cause infections in patients receiving hemodialysis and healthcareassociated bacteriuria primarily in elderly patients with diabetes.

Elizabethkingae meningoseptica is maximum sensitive to vancomycin (100\%) and Minocycline $(100 \%)$. It is comparable to study done by $\mathrm{Tak}^{26}$ et al., $\mathrm{Sinha}^{27}$ et al., showing isolate is sensitive to Vancomycin. Fraser ${ }^{28}$ et al., showed that the isolate is maximum sensitive to minocycline but resistant to vancomycin which is contraindicating from the present study.

\section{References}

1. Winn W Jr, Allen S, Janda W, Koneman E, Procop G, Schreckenberger P, et al., editors. Non fermenting gram negative bacilli. In: Koneman's colour atlas and textbook of diagnostic microbiology. $6^{\text {th }}$ ed.USA: Lippincott Williams and Wilkins company;2006.p.305-91.

2. Malini A, Deepa E K, Gokul B N, Prasad $\mathrm{S} R$. Non fermenting gram negative bacilli infections in a Teritiary care hospital in Kolar, Karnataka. J Lab physicians 2009;1(2):62-6.

3. Rajendra D, Ramana B V, Chaudhary A. Spectrum of Non fermenting GramNegative Bacilli Infection (excluding pseudomonas)in a Tertiary care Hospital. Int J Biol Med Res 2012;3(3):1902-1904.

4. Hill E B, Henry D A, Speert D P. Pseudomonas. In: Murray PR, Baron EJ, Jorgensen JH, Landry ML, Pfaller MA, editors. Manual of Clinical Microbiology,vol.1, $9^{\text {th }}$ ed. Washington, D.C: American Society for Microbiology; 2007.p.734-48.

5. Vijaya D, Kamala, Bavani S, Veena M. Prevalance of Non fermentors in Clinical Specimens. Indian J Med Sci 2000;54:8791.

6. Sajjad et al., Frequency and 
Susceptability pattern of Non fermenter Gram negative Bacilli In a Tertiary Care Hospital. Biomedica 2017;33(3):174-178.

7. Maniyan G, Vedachalam D, Chinnuswamy $\mathrm{N}$, et al., Characterization and antimicrobial susceptibility pattern of Non fermenting gram negative bacilli from various clinical samples in a tertiary care hospital. Indian J Microbiol Res 2016;3(4):387-391.

8. Ridhima W, Yash S, Upadhayay R P, Bala K. Nosocomial infection by Non fermenting Gram negative bacilli in a tertiary care hospital. Inter J Pharmacy Pharmaceutical Sci.2016;8(3):274-77.

9. Kalidas RIT, Falguni NAG, Hirak J R, Maity P K. Prevalance and susceptibility profiles of Non fermentative Gram negative bacilli infection in a tertiary care hospital of Eastern India. Ind $\mathrm{J}$ Clin Prac.2013;24(5):451-55.

10. Benachinmardi K K, Padmavathy $M$, Malini J, Naveeneth B V. Prevalance of Non fermenting Gram Negative Bacilli and their in vitro susceptibility pattern at a Teritiary care hospital in Birjung, Nepal. Int. J. Curr. Microbiol. App. Sci 2015;4(7):301-307.

11. Bruno D, Nishino $M$ K,Priore $W N$, Remus P R, Do Carmo A A, Stafanello V $\mathrm{B}$, et al., Prevalance of Gram negative non fermentors patients in porto AlegreRS. Jornal of Brasileiro de Patalogia e Medicinia Laboratorial. 2011;47:529-34.

12. Bhuvaneshwari G, et al., Multiple Antibiotic resistance indexing of Non fermenting gram negative bacilli.Asian $\mathbf{J}$ Pharm Clin Res 2017;10(6):78-80.

13. Khante S, Mate P, Raut S, Khadse R, Chavan S, et al., Prevalance of Non fermenters and their antibiogram at tertiary care hospital.Indian journal of Applied research 2019;9(7):76-77.

14. Samantha P, Gautam V, Thapar R, Ray P. Emerging resistance of non fermenting gram negative bacilli in a teritiary care centre. Indian J Pathol Microbiol 2011;54:666-7.

15. Eltahawy A T, Khalaf R M. Antibiotic resistance among gram negative non fermentative bacteria at a teaching hospital in Saudi Arabia.J Chemother 2001;13:260-4.

16. Wang H, Chen M J. China Nosocomial pathogens resistance surveillance study group. Changes of antimicrobial resistance among non fermenting Gram negative bacilli isolated from intensive care units from1994 to 2001 in china. Zhonghua Yi Xue Za Zhi 2003;83:38590.

17. Sudha Krishna et al., Prevalence of Non fermenting Gram Negative Bacilli and their Antibiotic Sensitivity Pattern at a Tertiary care Hospital in Tamilnadu, India. Int J Curr Microbiol App sci 2018;7(2):2751-2758.

18. Kaur A,Gill A K,Singh S, et al., Prevalance and antibiogram of Non fermenting gram negative bacilli isolates obtained from various clinical samples in a tertiary care hospital, Bathinda, Punjab, India. International journal of research in medical sciences 2018;6(4):1228-1234.

19. Nazir A, Peerzada B Y, Sana I, et al., Spectrum of Non fermenting gram negative bacilli isolated from patients with blood stream infections in a tertiary care hospital in north India. Int J Res Med Sci 2019;7(5):1762-1766.

20. Baruah F K, Hussian A N, Kausalya N, Grover R K. Antibiotic resistance profile of non fermenting gram negative bacilli isolated from the blood cultures of cancer patients.J Global Infect Dis 2015;7:46-7.

21. Memish Z A, Shibl A M, Kambal A M, Ohaly Y A, Ishaq A, Livermore D M. Antimicrobial resistance among nonfermenting gram negative bacteria in Saudi Arabia. J Antimicrobi chemother 2012;67:1701-5.

22. Jithendranath A, Radhika R, Bhargavi L, 
Bhai G, Bhai R, et al., Current trend of Non fermenting gram negative bacilli in a tertiary care hospital in Trivandrum. J Pure Appl Microbiol 2016;10(1):425-429.

23. Prasanna S, Dharanidevi S, Das K N, Raj S. Prevalance, Phenotypic Characterization and Antibiotic Susceptibility of Non-fermentative gram negative bacilli isolates at a tertiary care centre.Int J Curr Microbiol App sci 2016;5(11):442-454.

24. Parajuli P N, Acharya P S, Mishra K S, Parajuli K, Rijal P B, Pokhrel M B. High burden of antimicrobial resistance among gram negative bacteria causing health care infections in a critical care unit of Nepal. Antimicrobial resistance and infection control 2017;6(67):1-9.

25. Juyal D, Prakash R, Shankarnarayan S A, Sharma M, Negi V, et al., Prevalance of Non fermenting gram negative bacilli and their in vitro susceptibility pattern in a
Teritiary care hospital of uttarakhand: A study from foot hills of Himalayas. Saudi journal of health Sci 2013;2:108-12.

26. Tak V, Mathur P, Varghese P, Mishra M C. Elizabethkingia meningoseptica:An emerging pathogen causing meningitis in a hospitalized adult trauma patient. Indian J Med Microbiol 2013;31:293-5.

27. Shinha T, Ahuja R. Bacteremia due to Elizabethkingia meningoseptica.ID cases.2015;2:13-15.

28. Fraser S L, Jorgensen J H. Reappraisal of the antimicrobial susceptibilities of Chryseobacterium and Flavobacterium species and methods for reliable susceptibility testing. Antimicrob Agents Chemother.1997;41(12):2738-2741.

29. Clinical and laboratory standards institute(CLSI). Performance standards for antimicrobial susceptibility testing. $28^{\text {th }}$ edition.

CLSI

supplement.M100.Wayne,IN.2018.

\section{How to cite this article:}

Anirudh, Anil Bilolikar and Sukrutha Gopal Reddy. 2021. Emerging Non Fermentative Gram Negative Bacteria and their Antibiogram from Various Clinical Samples Collected from Patient Admitted to Medical Intensive Care Units. Int.J.Curr.Microbiol.App.Sci. 10(07): 514-524. doi: https://doi.org/10.20546/ijcmas.2021.1007.056 